\title{
Soil loss vulnerability: the case study of Aghien lagoon watershed outskirts Abidjan city (Côte d'Ivoire)
}

\author{
Amidou Dao ${ }^{1}$, Ehouman Serge Koffi ${ }^{1}$, Dabissi Djibril Noufé ${ }^{1}$, Bamory Kamagaté ${ }^{1}$, Lanciné Droh Goné ${ }^{1}$, \\ Luc Séguis $^{2}$, and Jean Louis Perrin ${ }^{2}$ \\ ${ }^{1}$ Laboratoire de Géosciences et Environnement, Université Nangui Abrogoua, \\ 02 BP 801 Abidjan 02, Côte d'Ivoire \\ ${ }^{2}$ IRD, UMR Hydrosciences, Université de Montpellier 2, Montpellier, France \\ Correspondence: Amidou Dao (daoamidou@ hotmail.fr)
}

Published: 16 November 2021

\begin{abstract}
Aghien lagoon is a source of fresh water outskirts of Abidjan city in the south of Côte d'Ivoire. For a better understanding of its functioning, we proposed to estimate its main tributaries (Bété and Djibi) soil loss during 2016 and 2017 as part of our research activities in the lagoon watershed in order to evaluate its vulnerability face to soil loss. The methodological approach is based on USLE (Universal Soil Loss Equation) incorporated into GIS (Geographic Information Systems). This equation takes into account five key factors: the erosivity of rainfall, the soil erodibility, the topographic factor integrating slope length and steepness, the covermanagement factor and the support practice factor. The combination of these factors made it possible to obtain soil loss maps of the lagoon main tributaries. The analysis of them revealed that soil loss varying mostly between 0 and $250 \mathrm{tha}^{-1} \mathrm{yr}^{-1}$ in 2016 and 2017. With regard to the two years, the vulnerability of the lagoon face to soil loss is "low" category. In fact, the soil loss class ranging from 0 to $20 \mathrm{tha}^{-1} \mathrm{yr}^{-1}$ occupies more than $60 \%$ of the two sub-basins area in 2016. This trend increased in 2017 with equivalent of $71 \%$ of the area. On the over hand, the "very high" vulnerability ranging from 250 to $1050 \mathrm{tha}^{-1} \mathrm{yr}^{-1}$, occupied in 2016 , only $0.01 \%$ of the area. In 2017, this category of vulnerability increased in intensity, occupying $0.05 \%$ of it. Ultimately, the increasing observed in 2016 and 2017 seems to be related to annual rainfall of respectively 1553 and $2198 \mathrm{~mm}$. The case study of Aghien lagoon, soil loss vulnerability can be improved by taking account a long time series of rainfall and land use data.
\end{abstract}

\section{Introduction}

Rain, characterized by its height, intensity and duration, defines potential erosion. Among the factors that modify the expression of climatic aggressiveness, the vegetation cover has by far the main role (variations 1 to 1000), then come the slope (1 to 50), the type of soil (1 to 10) and antierosion practices (1 to 10) (Roose and Lelong, 1976; Roose et al., 2014). However, human activities are catalysts that can profoundly alter the structure of soils. Thus, human activities, through agricultural practices, logging, grazing, transhumance or the construction of roads and buildings tend to modify erosion phenomena, often accelerating it considerably (Eblin et al., 2017). In Africa, the phenomenon of soil loss due to water erosion is very widespread, the majority of watersheds being characterized by severe specific degradation exceeding $2000 \mathrm{t} \mathrm{km}^{-2} \mathrm{yr}^{-1}$, which leads to siltation of dam reservoirs at a rate of 125 million meter cubes (Zouagui et al., 2018).

In Côte d'Ivoire, more precisely studies on water erosion carried out in the commune of Attecoubé (Abidjan) by N'Dri et al. (2008) and in the region of Bonoua by Aké et al. (2012) have highlighted evidence of strong soil loss due to water erosion. This sad observation extends to the entire Abidjan city, which is facing strong population growth and rampant urbanization to Aghien lagoon in its outskirts. This source of fresh water has been identified by the State of Côte d'Ivoire to alleviate the drinking water problems that the megalopolis has been face for nearly two decades. Indeed, two main 


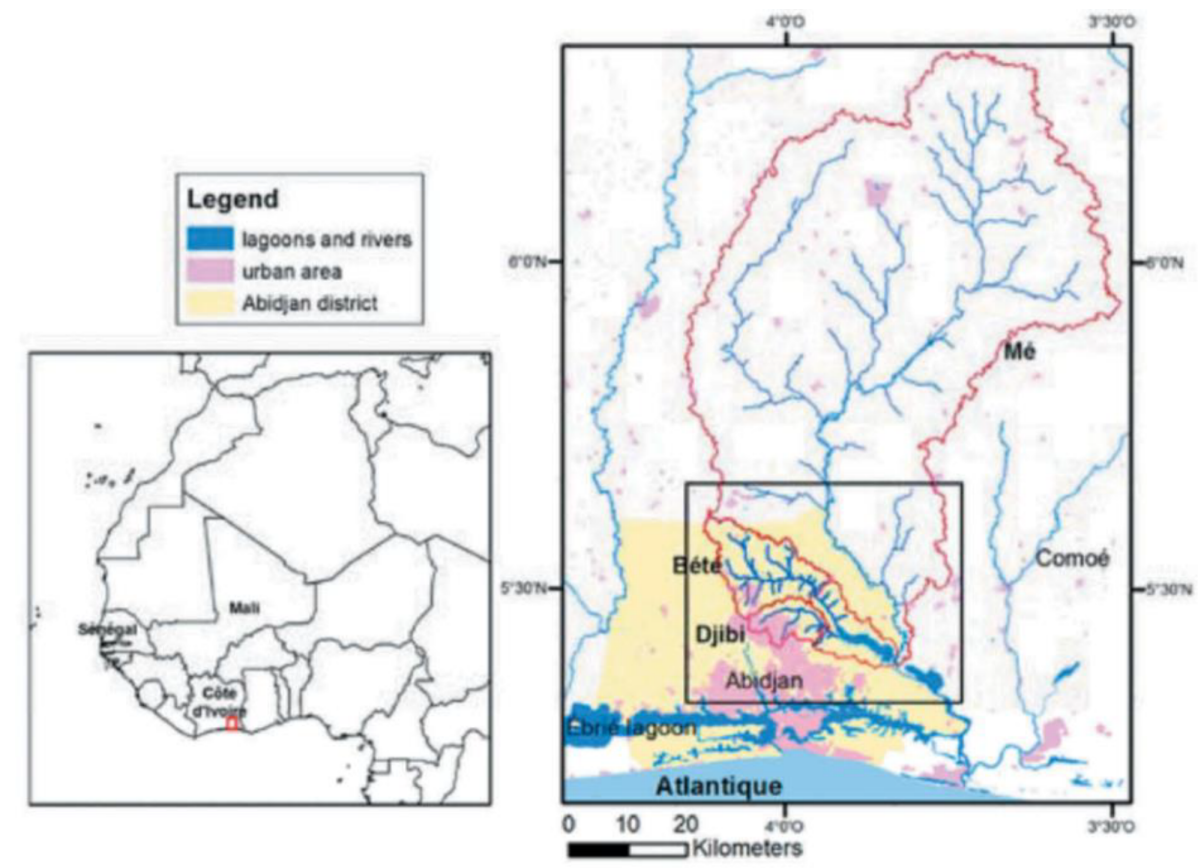

Figure 1. Study area (Ehouman et al., 2019).
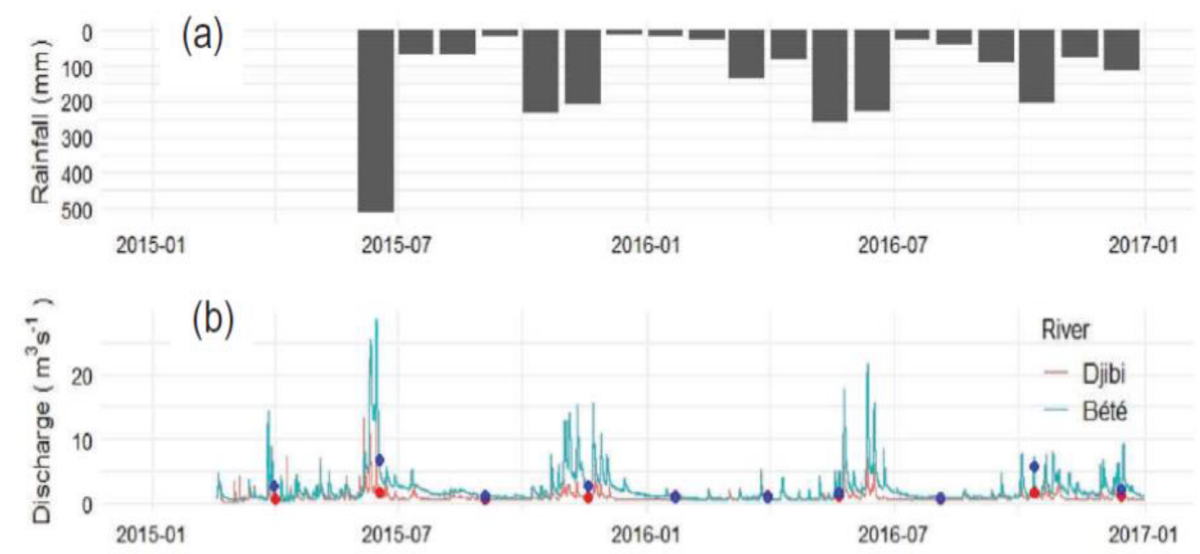

Figure 2. Rainfall (a) and Discharge (b) relationship in Aghien lagoon watershed (Ehouman et al., 2019).

tributaries (Bété and Djibi) feed this lagoon. Among them, Djibi's watershed is highly urbanized (Fig. 1).

Aghien lagoon watershed is influenced by a humid tropical climate characterized by 4 seasons: a large rainy season (March-July) and a short rainy season (October-November). The annual rainfall was $1553 \mathrm{~mm}$ in 2016 and $2198 \mathrm{~mm}$ in 2017. The other two periods correspond to more or less dry seasons. The hydrological regime is bimodal in close relation with the rainfall regime. Heavy rainfall occurs in June causing heavy floods, which define the potential water erosion (Fig. 2). According to Soro et al. (2004), Aghien lagoon watershed is located in a sedimentary environment formed mainly by tertiary and quaternary deposits made up of coarse sands, variegated clays, and ferruginous sandstones with iron ore. Since these formations are vulnerable to water erosion, Aghien lagoon watershed could be exposed to silting from soil loss. For a better understanding of how this lagoon works, we set out to estimate the soil loss that would contribute to its silting up due to water erosion from its main tributaries.

\section{Material and methods}

The material consists of a soil map of the sedimentary watershed of Côte d'Ivoire at a scale of 1:200000 from the archive of Vennetier (1973), a digital elevation model (DTM) 


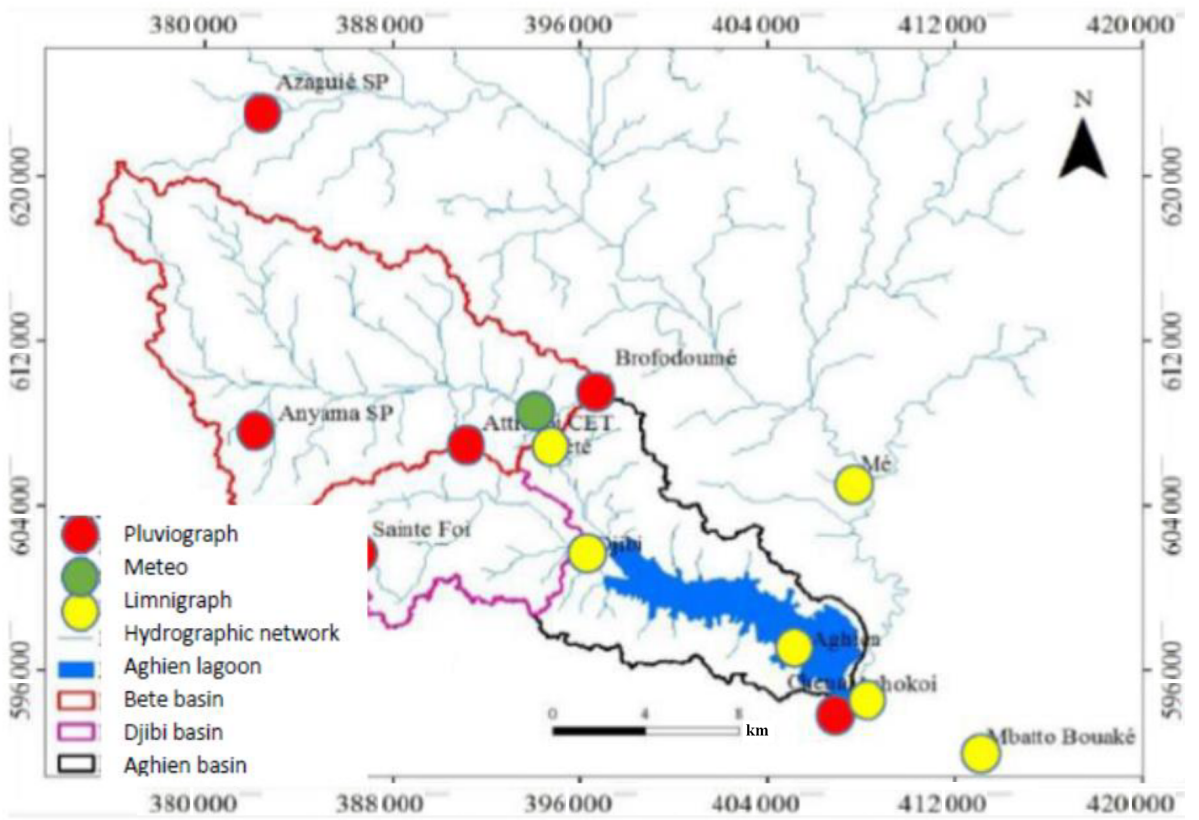

Figure 3. Hydroclimatic measurement network of Aghien lagoon watershed.

and Landsat 8 OLI images in resolution of $30 \mathrm{~m}$ for the years 2016 and 2017. The rainfall data come from six rainfallstations installed in the watershed as part of Aghien lagoon project (Fig. 3).

The method for estimating soil loss is based on USLE by taking account five key factors: the erosivity of rainfall, the soil erodibility, the topographic factor integrating slope length and steepness, the cover-management factor and the support practice factor. The USLE equation proposed by Wischmeier and Smith (1978) was the most widely used model in predicting the soil loss (Chadli, 2016). It is described by:

$A=R \cdot K \cdot L S \cdot P \cdot C$

where $A$ is the annual soil loss $\left(\mathrm{tha}^{-1} \mathrm{yr}^{-1}\right) . R$ corresponds to the erosivity of rainfall (MJ mm ha ${ }^{-1} \mathrm{~h}^{-1} \mathrm{yr}^{-1}$ ). This factor is expressed by the following equation:

$R=\sum_{n=1}^{12}\left(P_{i}^{2}\right) / P$.

$P_{i}$ is the monthly average rainfall $(\mathrm{mm}), P$ is the annual rainfall $(\mathrm{mm})$ and $n$ is the number of month. $K$ represents the soil erodibility factor (thah ha ${ }^{-1} \mathrm{MJ}^{-1} \mathrm{~mm}^{-1}$ ). It is established using the correspondence table of Stone and Hilborn (2012).

$L S$ is the topographic factor integrating slope length $(L)$ and steepness $(S)$ is expressed by:

$L S=\left(\frac{\lambda}{22.1}\right)^{m}\left(65.4 \sin \theta^{2}+4.56 \sin \theta+0.065\right)$.

$\lambda$ is the slope length (m), $\theta$ is the inclination of slope (\%) and $m$ is the factor established as a function of the slope.
Table 1. Variation of $m$ as a function of the slope (Payet et al., 2011).

\begin{tabular}{lc}
\hline Percentage of slope (\%) & Factor $m$ \\
\hline$\geq 5$ & 0.5 \\
$3.5 \leq \theta<5$ & 0.4 \\
$1 \leq \theta<3.5$ & 0.3 \\
$<1$ & 0.2 \\
\hline
\end{tabular}

Table 1 presents values of $m$ as a function of the slope percentage (Payet et al., 2011).

$C$ corresponds to the cover-management factor whose equation is:

$C=e^{-\left(\frac{\alpha \mathrm{NDVI}}{\beta-\mathrm{NDVI}}\right)}$

$\alpha$ and $\beta$ are determining the shape of the NDVI curve ( $\alpha=2$ and $\beta=1$ ). When the vegetation cover is continuous, erosion and runoff remain very low despite the aggressiveness of tropical rains.

$P$ corresponds to the support practice factor. The values of $P$ are between 0 and 1 , in which the value 0 represents a very good environment of resistance to erosion of human origin and the value 1 shows an absence of anti-erosion practice. See the soil conservation table recommended by Meliho et al. (2016).

All these factors cited are combined into GIS to develop soil loss maps. Spatial analysis, data combination, editing of thematic maps and setting up of GIS were carried out according to Fig. 4. 
Table 2. Erosion values by vegetation cover in Côte d'Ivoire (Roose and Lelong, 1976).

\begin{tabular}{lrrr}
\hline Rainfall stations & \multicolumn{3}{c}{ Erosion $\left(\mathrm{tha}^{-1} \mathrm{yr}^{-1}\right)$} \\
\cline { 2 - 4 } in Côte d'Ivoire & $\begin{array}{r}\text { Natural } \\
\text { environment }\end{array}$ & $\begin{array}{r}\text { Bare } \\
\text { ground }\end{array}$ & Culture \\
\hline $\begin{array}{l}\text { Adiopodoumé } \\
\text { (forest) }\end{array}$ & $0.03-1$ & $60-570$ & $0.1-90$ \\
\hline $\begin{array}{l}\text { Bouaké } \\
\text { (dense savannah) }\end{array}$ & $0.01-0.2$ & $18-30$ & $0.1-26$ \\
\hline $\begin{array}{l}\text { Korhogo } \\
\text { (clear savannah) }\end{array}$ & $0.1-0.2$ & $8-9$ & - \\
\hline
\end{tabular}

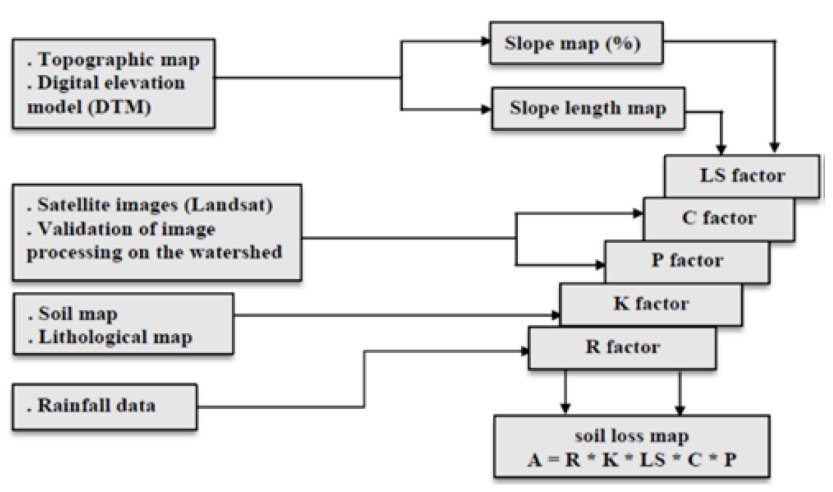

Figure 4. Methodology for estimating soil loss (Meliho et al., 2016).

\section{Results and discussion}

\subsection{Results}

\subsubsection{Estimation of Aghien lagoon tributaries' watershed soil loss}

Figures 5 and 6 are the results of thematic maps of the main factors involved in soil loss. Indeed, these maps show the tributaries' watershed of Aghien lagoon (see Fig. 3). Soil loss is varying essentially between 0 and $250 \mathrm{tha}^{-1} \mathrm{yr}^{-1}$ in 2016. It can be seen that the low soil loss classes $(0-$ $20 \mathrm{tha}^{-1} \mathrm{yr}^{-1}$ ) are very widespread in the watershed. On the contrary, the classes of high soil loss (50-1050 tha-1 $\left.\mathrm{yr}^{-1}\right)$ are not widespread and seems to follow the hydrographic network. In 2017, this observed trend is clearly increasing for high soil loss classes. The very high one goes from 250 to $1050 \mathrm{tha}^{-1} \mathrm{yr}^{-1}$.

\subsubsection{Vulnerability of Aghien lagoon face to its tributaries' watershed soil loss}

Vulnerability of the lagoon face to its tributaries' watershed soil loss is estimated by the area percentages. Percentages of soil loss area make it possible to assess the soil loss vul-

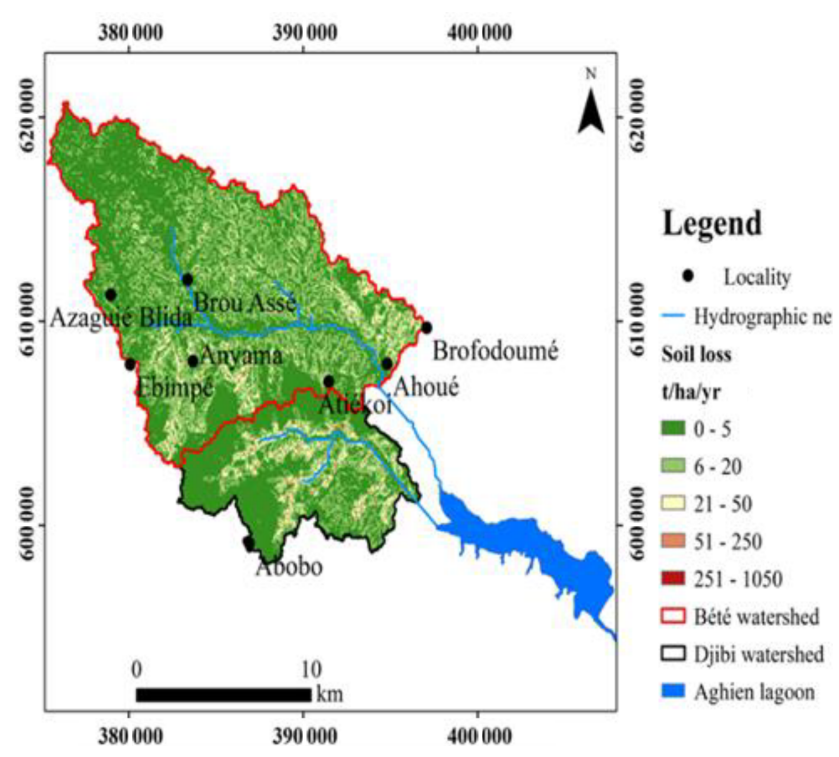

Figure 5. Soil loss in Aghien lagoon tributaries watershed (2016).

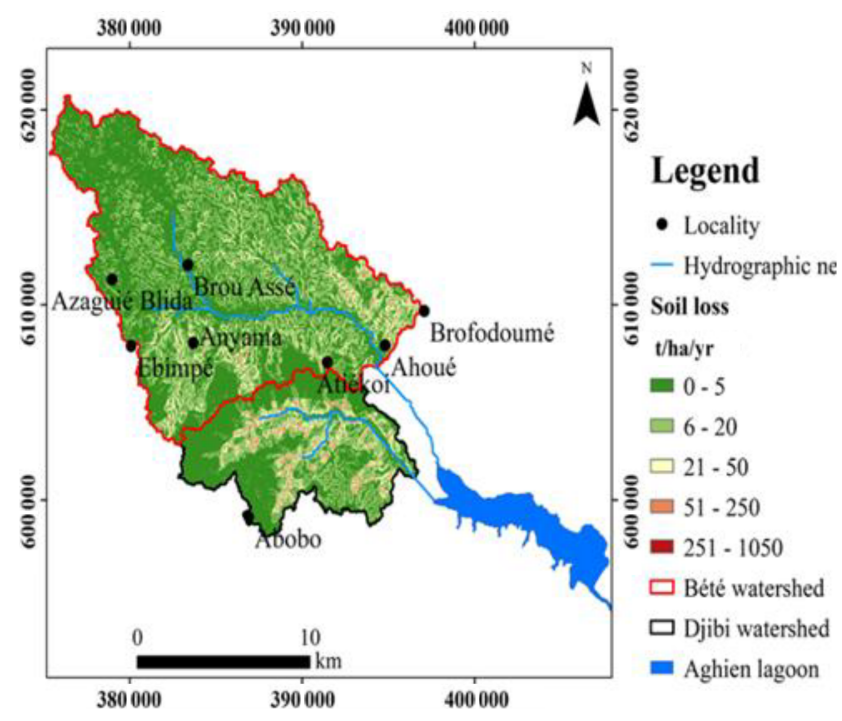

Figure 6. Soil loss in Aghien lagoon tributaries watershed (2017).

nerability ranging from "very low" to "very high" (Tables 3 and 4). With regard to the two years (2016 and 2017), the dominant vulnerability of the lagoon in connection with water erosion is "low" category. In fact, in 2016, the soil loss class ranging from 6 to $20 \mathrm{tha}^{-1} \mathrm{yr}^{-1}$ occupies more than $60 \%$ of the area of the two sub-basins. This trend increased in 2017 with soil loss area of 18210 ha, equivalent of $71 \%$ of the two tributaries area.

The "very low" vulnerability comes second with area percentages of $27 \%$ and $24 \%$ respectively in 2016 and 2017. The "very high" vulnerability ranging from 251 to $1050 \mathrm{tha}^{-1} \mathrm{yr}^{-1}$ in 2016 occupied only $0.01 \%$ of the area. 
Table 3. Vulnerability of Aghien lagoon to soil loss in 2016.

\begin{tabular}{lrrl}
\hline $\begin{array}{l}\text { Class of soil loss } \\
\left(\mathrm{tha}^{-1} \mathrm{yr}^{-1}\right)\end{array}$ & $\begin{array}{r}\text { Area } \\
(\mathrm{ha})\end{array}$ & $\begin{array}{r}\text { Area } \\
(\%)\end{array}$ & $\begin{array}{l}\text { Vulnerability } \\
\text { of the lagoon }\end{array}$ \\
\hline $0-5$ & 7071 & 27.55 & Very low \\
$6-20$ & 15552 & 60.59 & low \\
$21-50$ & 2650 & 10.32 & medium \\
$51-250$ & 393 & 1.53 & high \\
$251-1050$ & 3 & 0.01 & Very high \\
\hline
\end{tabular}

Table 4. Vulnerability of Aghien lagoon to soil loss in 2017.

\begin{tabular}{lrrl}
\hline $\begin{array}{l}\text { Class of soil loss } \\
\left(\mathrm{tha}^{-1} \mathrm{yr}^{-1}\right)\end{array}$ & $\begin{array}{r}\text { Area } \\
(\mathrm{ha})\end{array}$ & $\begin{array}{r}\text { Area } \\
(\%)\end{array}$ & $\begin{array}{l}\text { Vulnerability } \\
\text { of the lagoon }\end{array}$ \\
\hline $0-5$ & 6228 & 24.27 & Very low \\
$6-20$ & 18210 & 70.95 & low \\
$21-50$ & 971 & 3.78 & medium \\
$51-250$ & 244 & 0.95 & high \\
$251-1050$ & 12 & 0.05 & Very high \\
\hline
\end{tabular}

In 2017 , this category of vulnerability increased in intensity, occupying $0.05 \%$ of the sub-basins.

\subsection{Discussion}

The soil loss maps show that the areas where soil losses vulnerability are not dominant in the lagoon watershed (very low-to-low category), are very widespread and cover large areas (88\% in 2016 and $95 \%$ in 2017). These percentages are corresponding respectively to soil loss of 0 to $20 \mathrm{tha}^{-1} \mathrm{yr}^{-1}$ during the two years. These values can be classified in the same category as those obtained by Roose and Lelong (1976) in the same climatic zone in Côte d'Ivoire (see Table 2, the case of Adiopodoumé). They can be explained by the presence of abundant vegetation and gentle slopes (Roose et al., 2014). However, highly vulnerable areas occupy an infinite part with soil loss going to 251 to $1050 \mathrm{tha}^{-1} \mathrm{yr}^{-1}$ covering respectively area percentages of $0.01 \%$ and $0.05 \%$ respectively in 2016 and 2017. These high values of soil loss and low percentages of area can be due to the topographic factor integrating slope length along the hydrographic network (Payet et al., 2011). Overall, the increase in the risk of erosion between 2016 and 2017 in the watershed could be explained by rampant urbanization (see Fig. 1) and overgrazing leading to the destruction of the vegetation in progress (Aké et al., 2012). In addition, this degradation exposes the watershed to very strong runoff and very little infiltration (El hafid et Akdim, 2018). Soil displaced by erosion carries nutrients, pesticides and other chemicals (Benkaci et al., 2018). In the case of Aghien lagoon watershed, most of these harmful products can be carried by the two rivers to the lagoon (Ehouman et al., 2019). The assessment of soil loss gave high soil loss from 50-250, these values assigned to bare ground and culture (Roose and Lelong, 1976), are between the tolerance threshold which is $\left(1-12 \mathrm{tha}^{-1} \mathrm{yr}^{-1}\right)$ set by Kouadio et al. (2007). The deposition of soil loss and substances in the lagoon could contribute in the long term to its pollution and siltation, thus causing a drastic reduction of surface water (Meliho et al., 2016; Zouagui et al., 2018).

\section{Conclusion}

The aim of this paper was to study the soil loss vulnerability in Aghien lagoon watershed. The combination of the factors of the universal soil loss equation made it possible to obtain soil loss maps of the lagoon tributaries' watershed (Bété and Djibi). The results showed that soil loss varying mostly between 0 and $250 \mathrm{tha}^{-1} \mathrm{yr}^{-1}$. With regard to the two years (2016 and 2017), the dominant vulnerability of the lagoon in connection face to water erosion is "low" category. In fact, the soil loss class ranging from 0 to $20 \mathrm{tha}^{-1} \mathrm{yr}^{-1} \mathrm{oc}-$ cupies more than $60 \%$ of the two sub-basins area. This trend increased in 2017 with soil loss of $71 \%$. The "very low" vulnerability comes second with area percentages of $27 \%$ and $24 \%$ respectively in 2016 and 2017. The "very high" vulnerability ranging from 250 to $1050 \mathrm{tha}^{-1} \mathrm{yr}^{-1}$ in 2016 occupied only $0.01 \%$ of the area. In 2017, this category of vulnerability increased in intensity, occupying $0.05 \%$ of the sub-basins. Ultimately, this dynamic of water erosion correlated with strong anthropogenic pollution could compromise the use of Aghien lagoon as a freshwater reserve for Abidjan city. This work is a contribution to understand the functioning of Aghien lagoon. Applying the universal soil loss equation over a long series of rainfall and land use data could improve the results of this work.

Code availability. The GIS software used is Quantum GIS. The code is publicly accessible at https://www.qgis.org/fr/site/forusers/ download.html (QGIS, 2021).

Data availability. Data is available via the link: https://dataverse. ird.fr/dataverse/root?q=Aghien (Dataverse, 2021).

Author contributions. AD rote the manuscript with the data collected and compilated under quantum GIS software by ESK. DDN, BK and LDG read and correct the document. LS and JLP are our research partners within the framework of the Aghien lagoon project.

Competing interests. The contact author has declared that neither they nor their co-authors have any competing interests.

Disclaimer. Publisher's note: Copernicus Publications remains neutral with regard to jurisdictional claims in published maps and institutional affiliations. 
Special issue statement. This article is part of the special issue "Hydrology of Large River Basins of Africa". It is a result of the 4th International Conference on the "Hydrology of the Great Rivers of Africa", Cotonou, Benin, 13-20 November 2021.

Acknowledgements. Our thanks go to the "Debt Reduction and Development Contract" (C2D) between France and Côte d'Ivoire which funded the research activities of "Aghien lagoon" project through the partnership PReSeD-CI. This partnership was a very good collaboration between researchers from Université Nangui Abrogoua (UNA), in particular those from the "Laboratoire de Géosciences et Environnement" (LGE) and researchers from the French Institute for Research and Development (IRD).

Financial support. This research has been supported by the Contrat Desendettement Developpement (C2D) (Lot no. 4 du projet AMRUGE-CI - Appui à la Modernisation et à la Réforme des Universités et Grandes Ecoles de Côte d'Ivoire).

\section{References}

Aké, G. E., Kouadio, B. H., Adja, M. G., Ettien, J. B., Effebi K. R., and Biémi, J.: Cartographie de la vulnérabilité multifactorielle à l'érosion hydrique des sols de la région de Bonoua (Sud-Est de la Côte d'Ivoire), Physio. Geo., 6, 1-42, https://doi.org/10.4000/physio-geo.2285, 2012.

Benkaci, S., Abir, D., Oumellal, A., and Boualem, R. B.: Modélisation de l'érosion du bassin haut et moyen Cheliff par l'application Model builder sur ArcGis, J. Mater. Eng. Struct., 5, 81-93, 2018.

Chadli, K.: Estimation of soil loss using RUSLE model for Sebou watershed (Morocco), Model. Earth Syst. Environ., 2, 2-10, https://doi.org/10.1007/s40808-016-0105-y, 2016.

Dataverse: Des données ouvertes pour une science durable au Sud, available at: https://dataverse.ird.fr/dataverse/root?q= Aghien, last access: 19 October 2021.

Eblin, S. G., Yao, A. B., Anoh, K. A., and Soro, N.: Cartographie de la vulnérabilité multifactorielle aux risques d'érosion hydrique des sols de la région d'Adiaké, Sud-Est côtier de la Côte d'Ivoire, Rev. Ivoir. Sci. Technol., 30, 197-216, 2017.

Ehouman, K. S., Koffi, K. T., Perrin, J. L., Séguis, L., Guilliod, M., Droh, L. G., and Kamagaté, B.: Hydrological and water quality assessment of the Aghien Lagoon hydrosystem (Abidjan, Côte d'Ivoire), Hydrolog. Sci. J., 64, 1893-1908, https://doi.org/10.1080/02626667.2019.1672875, 2019.

El hafid, D. and Akdim., B.: Quantification De L'érosion Hydrique En Utilisant Le Modèle Rusle Et Déposition Intégrée Dans Un Sig, Cas Du Bassin Versant De L'oued Isly (Maroc Oriental), Eur. Scient. J., 14, 1857-7881, https://doi.org/10.19044/esj.2018.v14n5p373, 2018.
Kouadio, B. H., Kouamé, K. F., Saley, M., Biemi, J., and Traoré, I.: Insécurité climatique et géorisques en Côte d'Ivoire: étude du risque d'érosion hydrique des sols dans la région semimontagneuse de Man (Ouest de la Côte d'Ivoire), Sécheresse, 18, 29-37, 2007.

Meliho, M., Khattabi, A., Mhammdi, N., and Zhang, H.: Cartographie Des Risques De L'erosion Hydrique Par L'equation Universelle Revisee Des Pertes En Sols, La Teledetection Et Les Sig Dans Le Bassin Versant De L'ourika (Haut Atlas, Maroc), Eur. Scient. J., 12, 32, https://doi.org/10.19044/esj.2016.v12n32p277, 2016.

N’Dri, B. E., N'Go, Y. A., Kadio, H. N., Ouattara, A., Touré, B., and Biémi, J.: Effect of soil slope and cover on runoff and rate soil loss from experimental plots in area of Attécoubé, Eur. J. Scient. Res., 21, 459-470, 2008.

Payet, E., Dumas, P., and Pennober, G.: Modélisation de l'érosion hydrique des sols sur un bassin versant du sud-ouest de Madagascar, le Fiherenana, Vertigo, 11, 3, https://doi.org/10.4000/vertigo.12591, 2011.

QGIS: Un logiciel open source utilisant la licence GNU General Public License ce qui signifie que son code source peut être téléchargé via des archives tar ou un dépôt git at: https:// www.qgis.org/fr/site/forusers/download.html, last access: 20 October 2021.

Roose, E., Sabir, M., and Laouina, A.: Gestion durable des eaux et des sols au Maroc, OpenEdition Books, IRD Éditions, p. 343, https://doi.org/10.4000/books.irdeditions.294, 2014.

Roose, E. J. and Lelong, F.: Les facteurs de l'érosion hydrique en Afrique tropical, in: Etudes sur petites parcelles expérimentales de sol, 21, vol. xviii, fasc. 4, Revue de géographie physique et de géologie Dynamique, 18, 365-374, 1976.

Soro, N.; Lasm, T., Kouadio, B. H., Soro, G., and Ahoussi, K. E.: Variabilité du régime pluviométrique du Sud de la Côte d'Ivoire et son impact sur alimentation de la nappe d'Abidjan, Sud Sci Technol., 14, 30-40, 2004.

Stone, R. P. and Hilborn, D,: Universal Soil Loss Equation (USLE), Agdex\#: 572/751, 2012.

Vennetier, P.: Le milieu naturel de la Côte d'Ivoire, Les Cahiers d'Outre-Mer Année 1973 26-104, Les Cahiers d'Outre-Mer, p. 440, 1973.

Wischmeier, V. H. and Smith, D. D.: Predicting rainfall erosion losses- a guide to conservation planning, Agriculture Handbook No. 282, United States Department of Agriculture in cooperation with Purdue Agricultural Experiment Station, Washington, 1978.

Zouagui, A., Sabir, M., Naimi, M., and Benmansour, M.: Modélisation du risque d'érosion hydrique par l'équation universelle des pertes en terre dans le rif occidental: cas du bassin versant de Moulay Bouchta (Maroc), Eur. Scient. J., 14, 524-544, https://doi.org/10.19044/esj.2018.v14n3p524, 2018. 